Papers and Proceedings of the Royal Society of Tasmania, Volume 113, 1979

(ms. received 4.12 .1978 )

STRATIGRAPHIC RELATIONSHIPS OF LATE ORDOVICIAN TO EARLY DEVONIAN ROCKS IN THE HUNTLEY QUADRANGLE, SOUTH-WESTERN TASMANIA

by Peter Bailie

Geological Survey of Tasmania

(with three text figures and four plates)

ABSTRACT

BAILLIE, P., 1979 (20 vii): Stratigraphic relationships of Late Ordovician to Early Devonian rocks in the Huntley quadrangle, south-western Tasmania. Pap. Proc. $R$. Soc. Tasm., 113: 5-13 (incl. four plates). ISSN 0080-4703. Geological Survey of Tasmania, Department of Mines, Hobart, Tasmania, Australia.

During mapping of the Huntley Quadrangle in south-western Tasmania, two new, important, graptolite-trilobite-brachiopod bearing sequences were found in the upper part of the Lower Palaeozoic succession. The stratigraphy of these sequences is described. To avoid confusion a new group and a new formation, which includes the Westfield Beds (sensu Corbett and Banks 1974), are proposed.

\title{
INTRODUCTION
}

Geological studies of the Florentine Valley prior to that of Corbett and Banks (1974) are summarised in that paper. The Westfield Beds were defined therein as "that unit of buff-coloured siltstone and fine sandstone with some sandstone .... The base of the unit has not been seen and its upper contact with the Eldon Group is not yet clearly defined." In diagrams, and inferentially throughout the text, the Westfield Beds were used by Corbett and Banks (op. cit) as a lithostratigraphic unit quite distinct from, yet directly overlying the main limestone sequences of the Gordon Subgroup. Their separation from the overlying Eldon Group correlate was based not so much on lithological grounds, as a desire to characterise an Ordovician clastic sequence as distinct from a Silurian one.

Corbett and Banks (1975) redefined the Gordon Subgroup so as to include the Westfield Beds, but gave no criteria for recognising the top of the Westfield Beds or the base of the Eldon Group correlate.

The section described by Corbett and Banks in 1974, that is, the Westfield Road section, has weathered and deteriorated extremely rapidly. Nevertheless, the section must even then have been poorly exposed and unsatisfactory. In marked contrast, new sections at Westfield Quarry (and in its immediate environs) together with almost wholly exposed sections on Stan Murray Road and Range Road, indicate that the lithologies used to characterise the Westfield Beds by Corbett and Banks (1974) are repetitive and a comparatively minor element in a thick and essentially sandstone sequence.

Because of some confusion it is considered best to propose a new formation based on the excellent sections on Stan Murray Road and Range Road. This new formation spans the Ordovician - Silurian boundary, incorporates the Westfield Beds sensu Corbett and Banks (1974), and forms the uppermost unit of the Gordon Subgroup. 


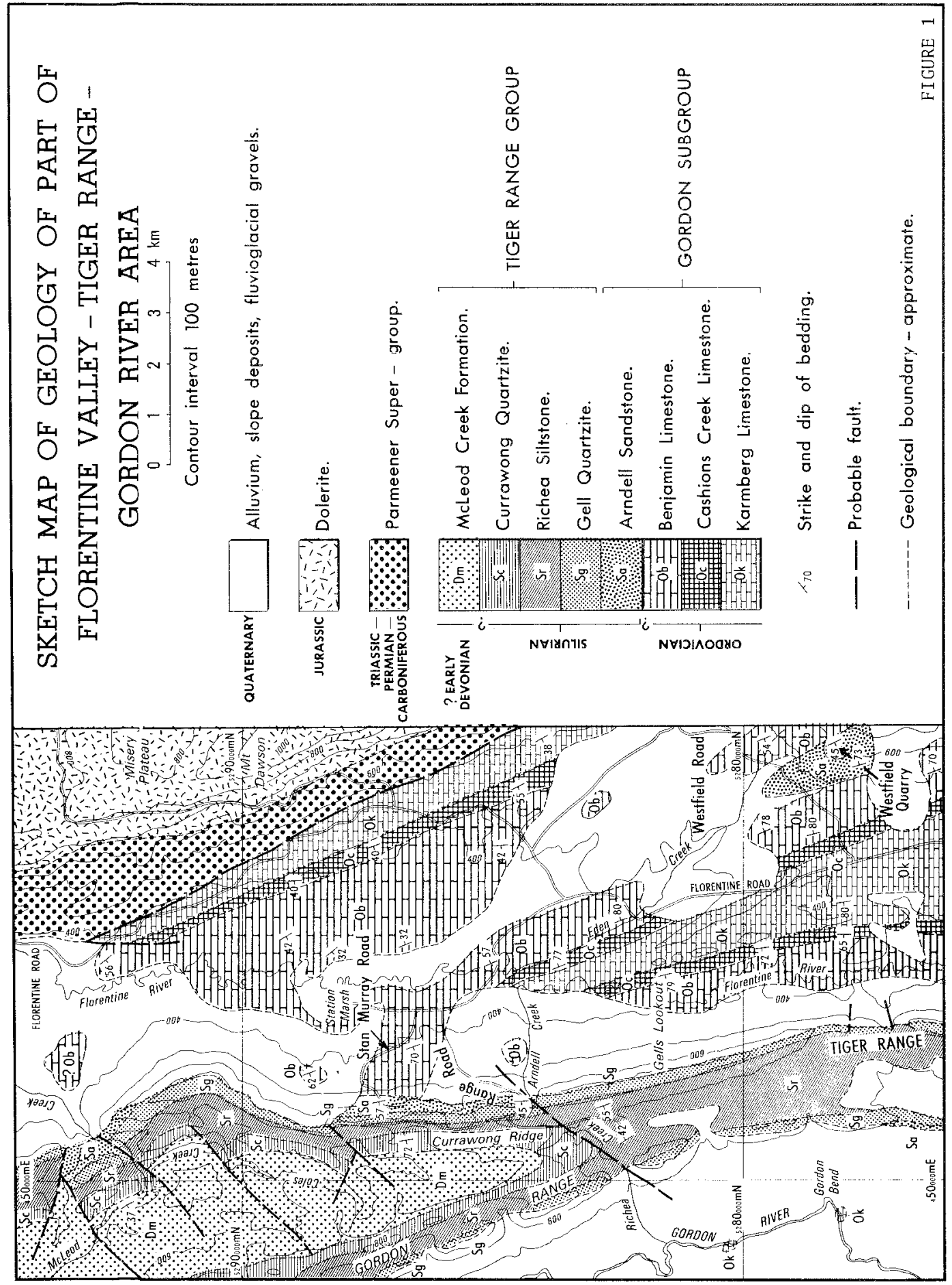


Peter Baillie

\section{STRATIGRAPHIC RELATIONSHIPS}

Details of the distribution of the formations is shown in figure 1 . The stratigraphic succession in the Tiger Range area may be summarised as follows (thicknesses estimated):-

$\left.\begin{array}{llr} & \text { McLeod Creek Formation } & 400+\mathrm{m} \\ \text { Tiger Range Group } & \text { Currawong Quartzite } & 150 \mathrm{~m} \\ & \text { Richea Siltstone } & 220 \mathrm{~m} \\ & \text { Gell Quartzite } & 130 \mathrm{~m} \\ \text { Gordon Sub-group } & \text { Arnde11 Sandstone } \\ & \text { Benjamin Limestone } \\ & \text { Cashions Creek Limestone } \\ & \text { Karmberg Limestone }\end{array}\right\}$

Gordon Sub-group

The 1imestone sequences of the Gordon Sub-group have been described by Corbett and Banks (1974). Only the top formation therefore will be discussed here.

Arnde11 Sandstone

Definition: This unit of buff-coloured siltstone and very fine-grained sandstone is about $250 \mathrm{~m}$ thick and overlies the Benjamin Limestone on both the eastem flanks of the Tiger Range and in the Westfield Quarry area. The formation is named after Arnde11 Creek [DN525843], a tributary of the Florentine River. The formation includes the Westfield Beds sensu Corbett and Banks (1974). The type section is a composite stratotype composed of the Stan Murray Road and Range Road sections.

Description: The base of the formation on Stan Murray Road consists of buff-coloured, micaceous siltstone. Bioturbation is often present. These siltstone layers underlie thinly-bedded, very fine-grained micaceous, quartz sandstone that have a maximum bedding thickness of $100 \mathrm{~mm}$.

On Range Road we11-1aminated beds of very fine-grained micaceous, quartz sandstone range in thickness from 40 to $400 \mathrm{~mm}$. Siltstone is only a minor part of the sequence. Herringbone-type cross bedding is occasionally present. Other sedimentary structures include scours and dewatering structures. Vertical feeding-burrows are common and other bioturbation structures are often present. Towards the top of the formation there are beds of coarser, quartz sandstone up to 1 metre in thickness.

In the Westfield area the sequence consists of siltstone and fine-grained sandstone with sandstone becoming more common upwards. The top of the formation has been removed by erosion.

Palaeontology: The formation is richly fossiliferous at many horizons (fig. 2). Brachiopods, trilobites, Bryozoa, graptolites and Bivalvia are present in siltstone, and brachiopods and solitary rugose corals are present in the sandstones.

Atavograptus sp., Glyptograptus perscuzptus (Salter), climacograptus normatis Lapworth and ?Akidograptus sp., from an horizon at Westfield Quarry, some $150 \mathrm{~m}$ above the base of the formation, indicate an Early Llandovery perscuzptus to low acuminatus zonal age (Bailiie, Banks and Rickards 1978). On Range Road [DN515843] there are bands rich in Eospivifer sp. nov., probably the earliest occurrence of strophic spiriferids, (P.M. Sheehan pers. comm). Other aspects of the palaeontology of this formation are discussed in Corbett and Banks (1974), Baillie and Clarke (1976), and Bailitie et $a z$. (1978). 
Late Ordovician to Early Devonian Rocks in the Huntley Quadrangle

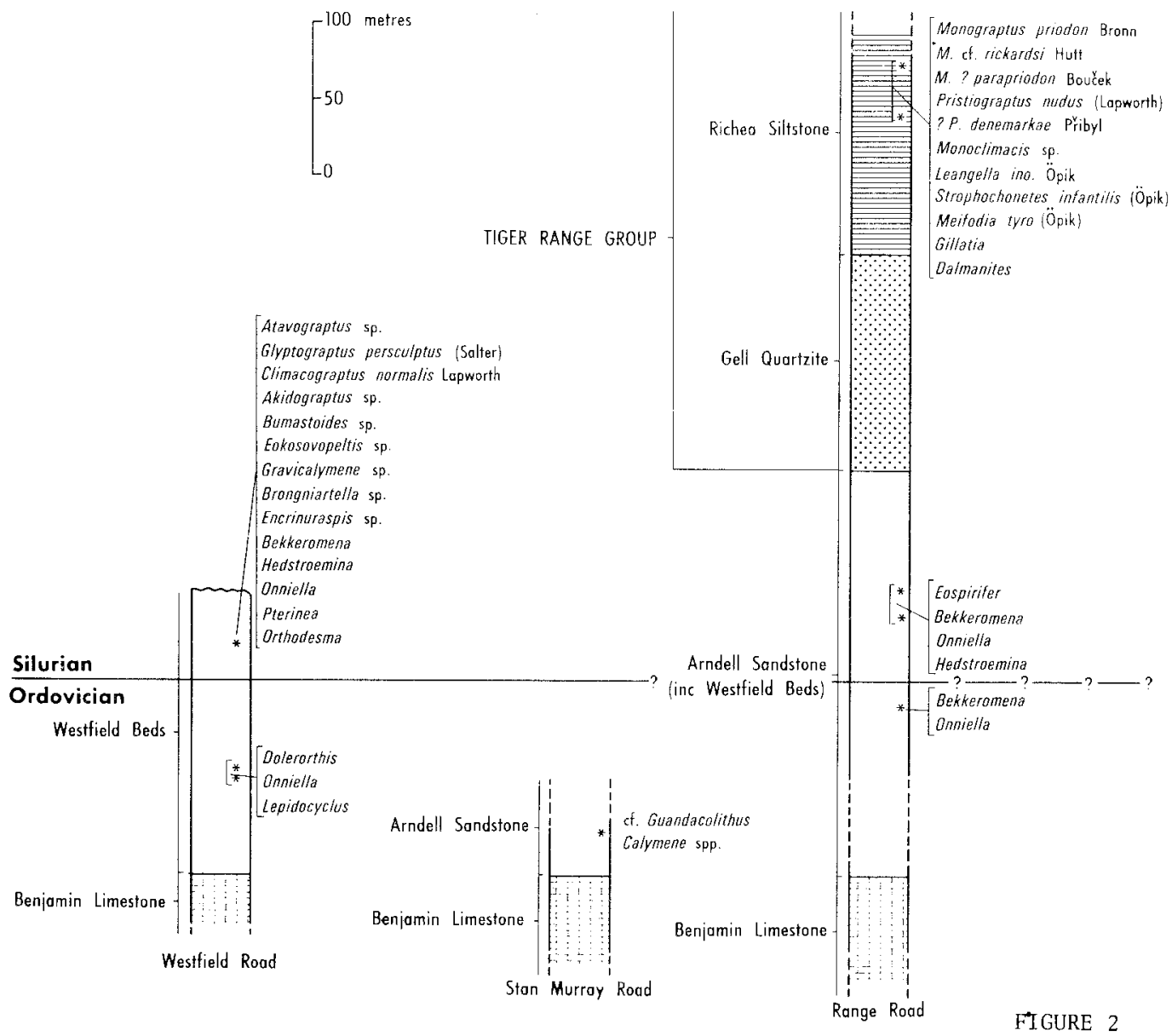

\section{Tiger Range Group}

The Tiger Range Group is defined as consisting of, in ascending stratigraphic order, the Geli Quartzite, the Richea Siltstone, the Currawong Quartzite and the McLeods Formation. These formations are defined below. The Tiger Range Group has a total thickness in excess of $900 \mathrm{~m}$ and ranges in age from Early Silurian to probable Early Devonian. The sequence is of shallow-water marine origin and is a lithostratigraphic correlate of the Eldon Group of Western Tasmania.

The type area is in the Tiger Range, in the vicinity of Range Road and Coles Creek.

Gel1 Quartzite

Definition: The formation is composed of the hard grey quartzite forming the prominent topographic ridge along the eastern edge of the Tiger Range. It has a maximum thickness of about $130 \mathrm{~m}$. The type section is exposed on Range Road near the headwaters of Arndell Creek. 
Peter Baillie

Description: The formation consists of beds of hard, grey orthoquartzite ranging in thickness from $20 \mathrm{~mm}$ to over $2 \mathrm{~m}$, but usually from $400-600 \mathrm{~mm}$.

The rocks are fine to very fine-grained as seen in thin sections (specimens 76-562, 76-563, 76-564 in the Department of Mines collection). The finer grained rocks (specimens $76-562,563$ ) are moderately to well sorted (So $1.2-2.0$ ), and consist of angular to subrounded grains of quartz, rock fragments, plagioclase (albite) and detrital mica. Heavy minerals may be present. The quartz grains are of single crystals which often show undulose extinction resulting from strain. The matrix often contains carbonaceous material. The presence of some strained quartz grains and albite indicates that a metamorphic terrain formed part of the original source area. The fine sandstone (specimen 76-564) is well sorted (So $1.2-1.4$ ), and individual grains are more rounded than the grains of the very fine sandstone. The rock is more mature than the very fine-grained sandstone with only occasional rock fragments present.

The tops of the sandstone beds may be scoured and may show oscillation or interference ripples (plate 1 ). Worm casts may be present on the tops of some ripples (p1ate 2). The sandstone beds often show internal bioturbation.

Some thin, micaceous and ?carbonaceous mudstone is interbedded with the orthoquartzite but forms only a minor part of the sequence. There is a gradational contact over a short stratigraphic interval between this formation and the overlying Richea Siltstone, with siltstone becoming more common upwards in the sequence.

The presence of oscillation ripples in sandstone probably indicates deposition in shallow water associated with wave action (e.g. Conybeare and Crook 1968). Interference ripples are commonly formed in shallow water, where shallowing of the sea floor, or coastal topography, causes deflections of the wave pattern (Conybeare and Crook 1968).

Richea Siltstone

Definition: That formation of brown and green siltstone lying above the Gell Quartzite and below the Currawong Quartzite. Maximum thickness is of the order of $130 \mathrm{~m}$. It is best exposed in road cuttings on Range Road and the branch of Range Road that follows the western side of Gells Lookout.

Description: The formation consists of a uniform sequence of we11-bedded, buff to grey-green, micaceous siltstone. Bioturbation is usually present. Thin, fine-grained sandy layers also occur.

Palaeontology: Tow richly fossiliferous horizons are known. The monograptids present indicate a very late Llandovery age of either the crenulata or griestoniensis Zones (Baillie 1977). The most common graptolite found is Monograptus priodon Bronn, stipes of which are often current oriented (plate 3). Other monograptids include M. c.f. mickardsi Hutt, M.?parapriodon Boucek, Pristograptus nudus (Lapworth), PP. denemarkae Pribyl, Monoclimacis and a single specimen of either Cyrtograptus or M. tullbergi Boucek. Figure 3 shows the ranges of graptolites found in this formation. Other fossils found include very well-preserved Dalmanites sp., brachiopods including Leangella ino Öpik, Strophochonetes infantilis (Öpik) Meifodia tyro (Öpik), ostracods and rare asterozoans.

Currawong Quartzite

Definition: This formation of hard, white quartzite forms Currawong Ridge [DN509850]. Maximum thickness is of the order of $150 \mathrm{~m}$. The base of the formation is best exposed in road cuttings immediately north of the quarry at the northern end of Currawong Ridge. The top of the formation has been observed only in Coles Creek. 


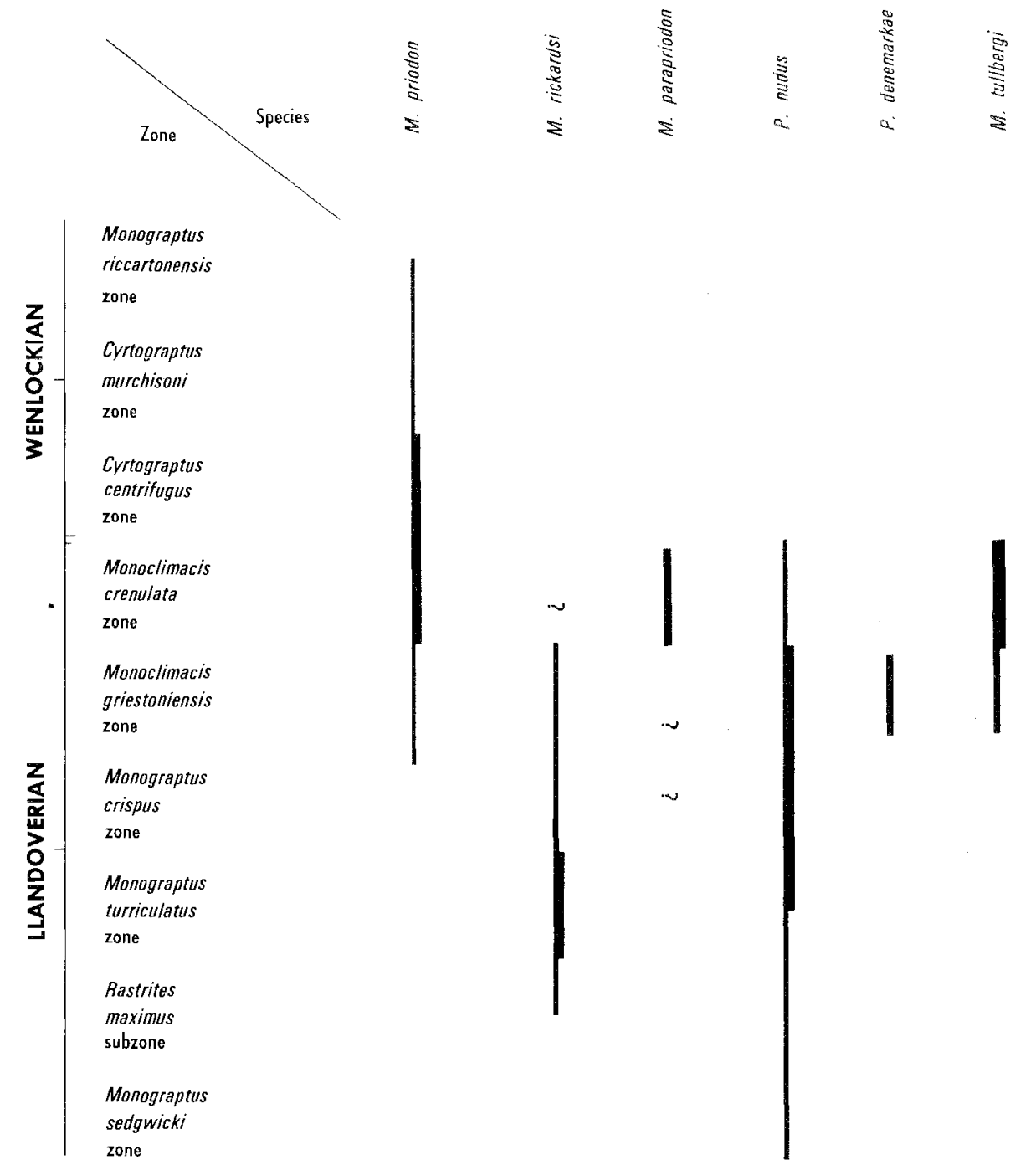

RANGES OF GRAPTOLITES [after RICKARDS (1976)]

FIGURE 3 FOUND IN RICHEA SILTSTONE 
Peter Baillie

Description: The formation consists of interbedded massive quartzite in beds $300-$ $800 \mathrm{~mm}$ thick with minor grey laminated micaceous siltstone in beds 40 - 150 mm thick. The sandstone beds are not graded and have sharp tops and bottoms. Thin sections (specimen 78 - 842) of a sandstone shows it to be of extremely we11-sorted (So 1.0 1.1), very fine-grained quartz with some detrital mica grains. Individual quartz grains are subangular to we11-rounded. Some of the sandstone show bioturbation. The siltstone is generally well laminated and may contain authigenic pyrite (specimen 78 843 ).

Like the Gell Quartzite the tops of some of the sandstone beds show well-developed oscillation ripples (plate 4).

Palaeontology: The formation is poorly fossiliferous but Nucleospira, Lissatrypa, Leangella, Strophochonetes, Isorthis, ?Howellezla, heliolitids, favositids and solitary rugose corals are present. The presence of sucleospira and leangella suggest a Late Silurian age (M.J. Clarke pers. conm).

McLeod Creek Formation

Definition: The formation consists of the thinly-bedded, grey micaceous fine-grained sandstone and dark-grey, micaceous mudstone overlying the Currawong Quartzite. It is best exposed in Coles Creek and its tributaries, including McLeod Creek [DN495923]. The thickness is greater than $400 \mathrm{~m}$. The top of the formation has been removed by erosion.

Description: This formation was seen on $1 y$ in Coles Creek where it consists of thinlybedded, grey, micaceous fine-grained sandstone and siltstone in beds $40-200 \mathrm{~mm}$ thick. The upper part of the formation consists of well-bedded, dark-grey, micaceous siltstone and mudstone in beds up to $250 \mathrm{~mm}$ in thickness.

The formation is unfossiliferous.

\section{ACKNOWLEDGEMENTS}

The author gratefully acknowledges the help given in the field by Mr. M.J. C1arke. He also thanks Mr. Clarke for helpful discussion and critical reading of the manuscript. The manuscript was also critically read by Dr. N. Farmer and Dr. E. Williams, Geological Survey of Tasmania. The graptolites were identified by Dr. R.B. Rickards, Sedgwick Museum, University of Cambridge. M.J. Clarke identified the other fossils quoted in the text. The figures were draughted by T.R. Bellis. This paper is published by permission of the Director of Mines, Tasmania.

\section{REFERENCES}

Baillie, F.W., 1977: Further comments on Early Palaeozoic (Late ordovician - Early Silurlan) graptolites in the Huntley quadrangle. Unpubz. Rep. Dep. Mines Tasm., $1977 / 19$.

and Clarke, M.J., 1976: Preliminary comments on Early Palaeozoic (Late Ordovician - Early silurian) rocks and fossils in the Huntley quadrangle. Unpub2. Rep. Dep. Mines Tasm., 1976/41.

Banks, M.R. and Rickards, R.B., 1978: Early Silurian Graptolites from Tasmania and their significance. Search, 9(1-2): 46-7.

Conybeare, C.E.B. and Crook, K.A.W., 1968: Manual of Sedimentary structures. Bur. Miner. Resour. Aust. Bulz., 102.

Corbett, K.D. and Banks, M.R., 1974: Ordovician stratigraphy of the Florentine Synclinorium, southwest Tasmania. Pap. Proc. R. Soc. Tasm., 107: 207-238. 
Late Ordovician to Early Devonian Rocks in the Huntley Quadrangle

Corbett, K.D. and Banks, M.R., 1975: Revised terminology of the Late Cambrian Ordovician sequence of the Florentine - Denison Range area, and the significance of the "Junee Group". Pap. Proc. R. Soc. Tasm., 109: 121-126.

Rickards, R.B., 1976: The sequence of Silurian graptolite zones in the British Isles. Geol. J., $11(2): 153-188$.

\section{PLATE EXPLANATION}

PLATE 1 (top 1eft): Oscillation ripples, Gell Quartzite; Range Road (DN571587).

PLATE 2 (top right): Oscillation ripples with worm casts, Ge11 Quartzite; Range Road (DN 511587).

PLATE 3 (centre): Current oriented stipes of Monograptus priodon, x 1.3, Richea Siltstone; branch of Range Road (DN 512838).

PLATE 4 (bottom): Oscillation ripples in Currawong Quartzite; quarry at north end of Currawong Ridge (DN 508860). 
Peter Baillie
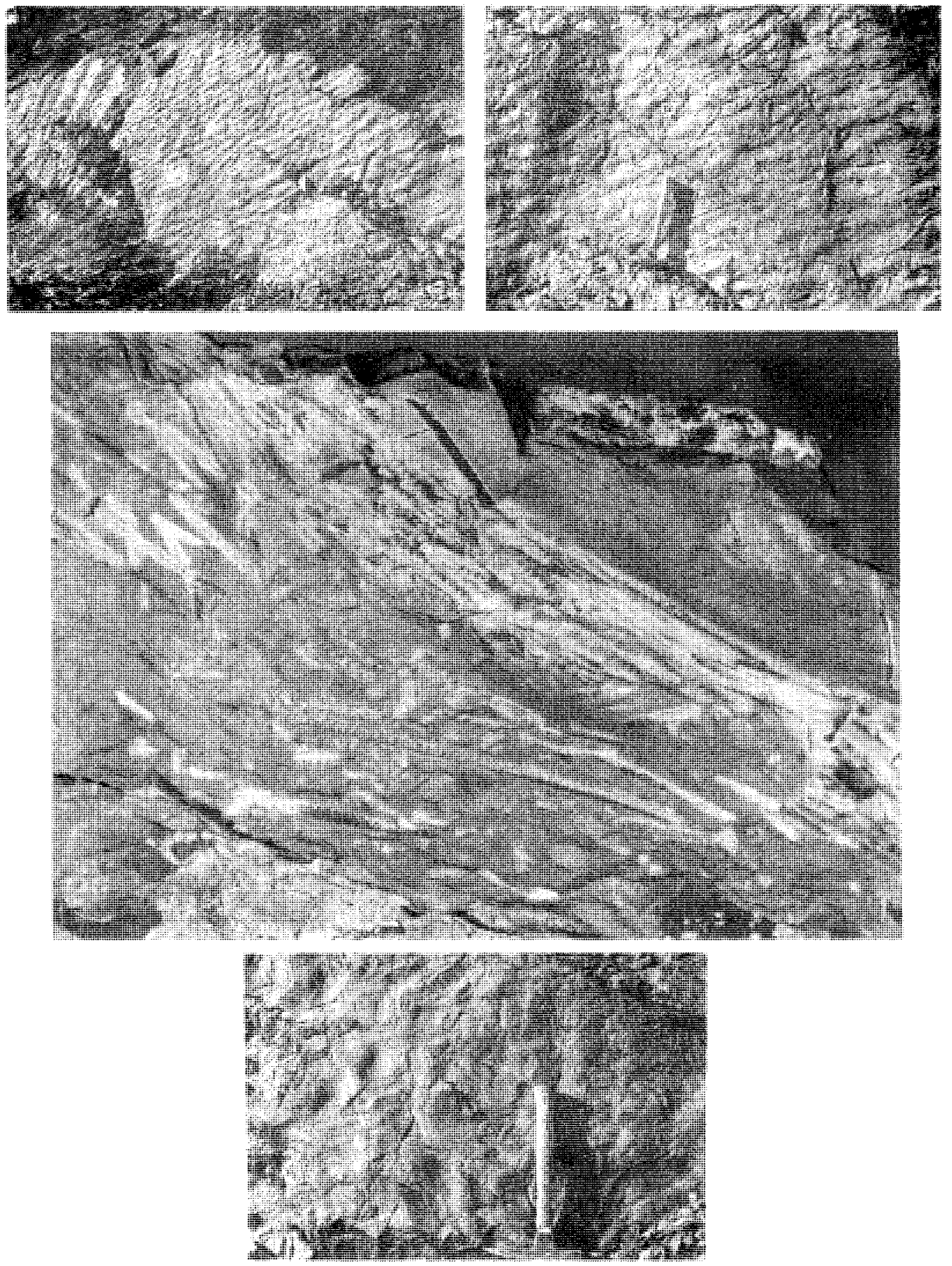